\title{
RESEARCH ON THE STRUCTURE OF THE BENTHIC BIOCENOSIS OF OLĂNEŞTI RIVER
}

\author{
Alina - Mihaela Truță ${ }^{1}$ * \\ ${ }^{1}$ University of Piteşti, Faculty of Sciences, Physical Education and Informatics \\ Târgul din Vale Street, no 1, Piteşti, Romania
}

\begin{abstract}
The Olăneşti River is part of the Olt Basin, springs from the Căpățânii Mountains and flows in a south-southeast direction, flowing into the Olt River south of the municipality of Rm. Vâlcea, after covering a route of $38 \mathrm{~km}$. It has as tributaries the following rivers: Stoica, Comanca, Cheia, Câinelui and Izvoarele Olăneşti.

Through this study we aimed to characterize the phyto and zoobenthic structure of the Olanesti River. In order to achieve the proposed goal, the following objectives were taken into account: identification of the taxa that make up the phyto and zoobenthic biocenoses; systematic classification of identified species; establishing the ecological spectrum of families and the relative abundance of macrozoobenthos species; establishing the saprob index and the saprobe value for each river sector studied. Following the research carried out on the Olăneşti River regarding the structure of the benthic biocenosis, 34 phytobenthic species belonging to Phyllum Bacillariophyta and 23 zoobenthic species were identified. The analysis of the ecological spectrum reveals the largest share in the Baëtidae family. The saprobic value for each station is below 1.65 indicating that the whole river is in the $\beta$-mesosaprobic zone, respectively the good ecological status.
\end{abstract}

Keywords: environmental quality, Olăneşti River, phyto and zoobenthic structure

\section{INTRODUCTION}

As part of Olt basin, Olăneşti River springs from Căpățânii Mountains and flows in a southsoutheast direction, flowing into Olt River, south of Rm. Vâlcea town, after crossing a route of 38 $\mathrm{km}$ (figure 1). Its tributaries are Stoica River, Comanca River, Cheia River, Câinelui River, Izvoarele Olăneşti River. In the mountain area it has a typical aspect of a mountain river, with clean shallow and highly oxygenated water. This part is crossed by lands with hard rock, distinguished in the riverbed by large fragments of rock, conglomerates with boulders and gravels. In the quieter parts, at turns, there appear deposits of coarse and medium sands, often within a limited area. Due to the steep slope, the flow rate is high, and in some places small waterfalls are formed, which contribute to the aeration of the water. The width of the riverbed is 5-6 meters, and the depth varies between $0.20-0.60$ meters. The water temperature is relatively little influenced by the air temperature and the thermal regime has lower values.

The water transparency is high, the water has practically no color (in the thick layer it appears slightly greenish) and no smell. Following heavy rains, the water flow increases shortly, the river carries large amounts of fragmented rock, sand, branches and trunks, getting a light gray color with 


\section{Current Trends in Natural Sciences \\ Vol. 9, Issue 17, pp. 322-336, 2020 \\ https://doi.org/10.47068/ctns.2020.v9i17.041}

Current Trends in Natural Sciences (on-line)

ISSN: 2284-953X

ISSN-L: 2284-9521
Current Trends in Natural Sciences (CD-Rom)

ISSN: 2284-9521

ISSN-L: 2284-9521

a yellowish tinge. Highly-oxygenated water favors the presence of a biocenosis typical of the oligobetamezosaprobe area.

In terms of hydrobiology, Olăneşti River has in this part a single aspect with great extension, the lotic biotope of the erosion bottom. The watercourse favors a good development of life, removing the products of disassimilation, as well as decaying matter resulting from the death of organisms. The lentic biotope appears in small portions towards the banks, on the bottom of the sediment.

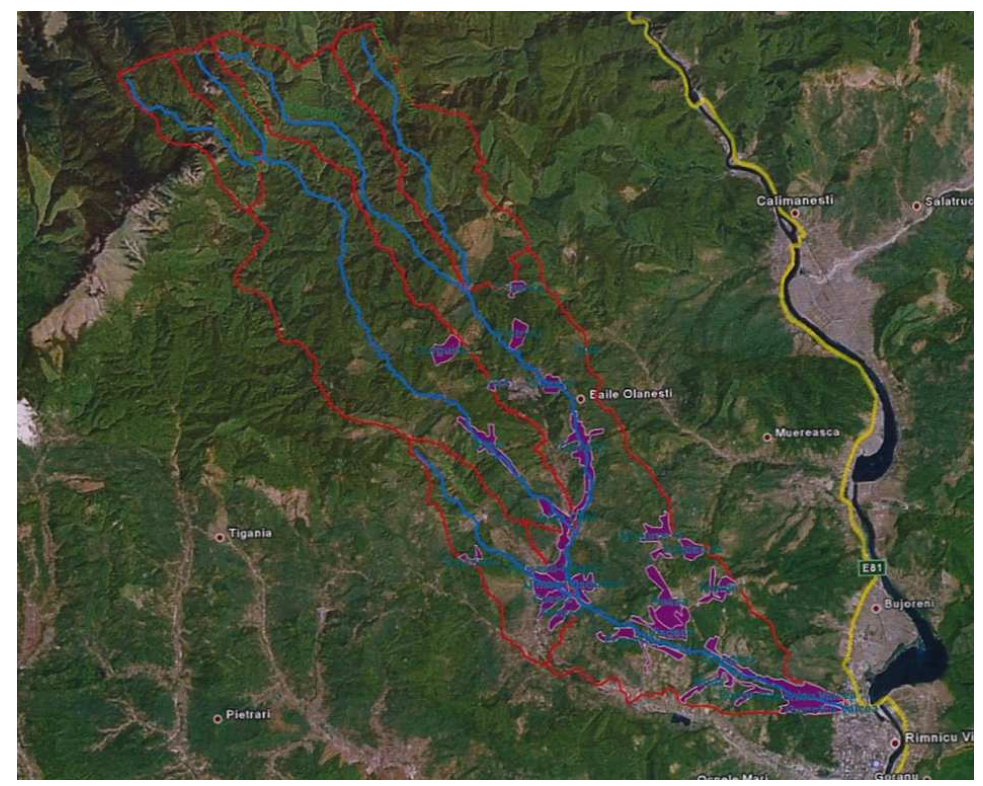

Figure 1. Olăneşti Hydrographic Basin

(http://www.rowater.ro/daolt/PROIECTE\%20REALIZATE/PPPDEI/Prezentare\%20finala\%20proiect_PPPDEI_BH.OLT.pdf)

The river meadow is very narrow and is used for growing vegetables and corn.

Since during the spring and autumn rains it brings a lot of floods and overflows, the course of Olăneşti river was regulated by dam works (figure 2). The natural course of the river was blocked near Olăneşti-Băi area, and on the territory of the neighboring township - Vlădeşti (10 km upstream of Rm. Vâlcea town) there was built a dam behind which a storage basin was formed. In addition to the source of water for electricity production, the basins formed also aim to:

- retain slime on Olăneşti River;

- protect Rm. Vâlcea town against floods;

- exploit fish through populating with productive species.

These interventions have greatly reduced the flow of the river, downstream Vlădeşti. In the area of $\mathrm{Rm}$. Vâlcea there are important changes with involution and puddles due to upstream impurities on the background of a low flow.

The main sources of pollution on Olăneşti River are:

- riparian rural areas (household waste);

- Olăneşti-Băi town (decanted fecal-wastewater);

- Vlădești military unit (partially treated fecal-wastewater);

- U.G.I.R.A. (wastewater);

- accidental pollution due to leaks or intended spills of cyanides, hypochlorite, phenolic compounds or soaps. 


\section{Current Trends in Natural Sciences}

Vol. 9, Issue 17, pp. 322-336, 2020

https://doi.org/10.47068/ctns.2020.v9i17.041

Current Trends in Natural Sciences (on-line)

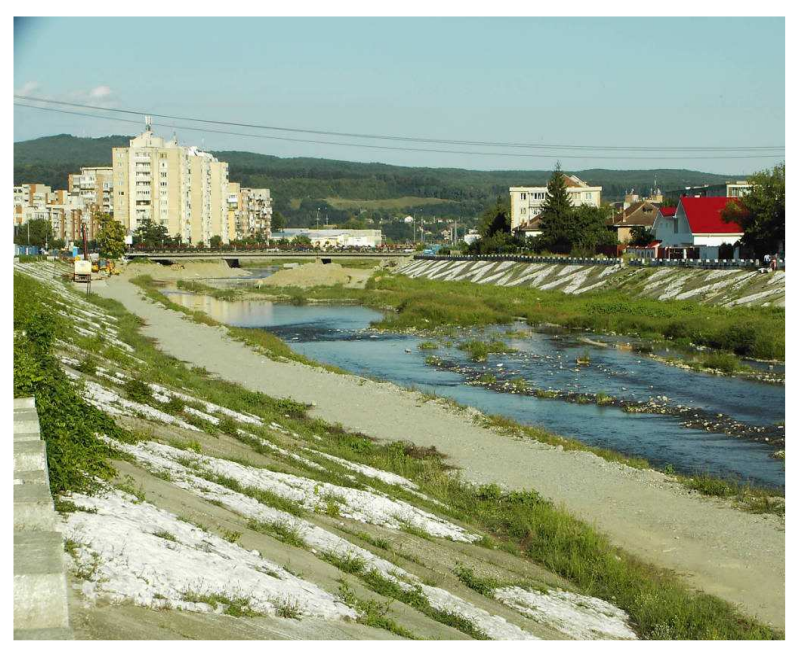

Figure 2. Regulation of Olăneşti River by damming

Olăneşti River changes its appearance in the south as it crosses a hilly area with alluvial lands. There are deposition areas with a slower slope and lower water speed.

The widening of the riverbed, as well as its stagnation in open places following the regulation of the river course makes the water temperature to be more influenced by that of the air, the thermal regime showing high oscillations during the year. The transparency of the water depends on the amount of suspensions and differs from one season to another. In summer and winter there are high values of transparency; instead, after the rainfall in spring and autumn, the water flow increases quickly, the water causes large amounts of suspensions and the transparency is extremely low. The concentration of dissolved oxygen is closely correlated with variations in water temperature. In the area of Rm. Vâlcea, the riverbed has an average width of $7-8$ meters with an average depth of 0.15-0.4 meters. The riverbed is made of gravel and sand, due to which the water line often moves from one border to another. Due to the frequent fluctuations of the water line, which created a wide minor riverbed, the banks of Olăneşti River were fixed by sloping in the town area.

\section{MATERIALS AND METHODS}

To establish the phyto and zoobenthos structure of Olăneşti River, qualitative and quantitative samples were taken from 3 stations: Olăneşti, Cheia and Vlădeşti, thus covering the entire course of the river, taking into account the morphohydrological changes and anthropogenic impact.

Station 1 - Olăneşti (figure 3)

- seasonal influence of tourism, from May to September;

- deciduous area;

- steep banks with grassy vegetation;

- bioderm developed in the summer months;

- cloddish underlayer with large stones;

- average depth 25-35 cm.

\section{Station 2 - Cheia (figure 4)}

- anthropogenic influence;

- deciduous area;

- steep banks with grassy vegetation;

- bioderm developed in the summer months; 


\section{Current Trends in Natural Sciences}

Vol. 9, Issue 17, pp. 322-336, 2020

https://doi.org/10.47068/ctns.2020.v9i17.041

Current Trends in Natural Sciences (on-line)

ISSN: 2284-953X

Current Trends in Natural Sciences (CD-Rom)

ISSN: 2284-9521

ISSN-L: 2284-9521

ISSN-L: 2284-9521

- cloddish underlayer with large stones;

- average depth 25-35 cm.

Station 3 - Vlădeşti (figure 5)

- anthropogenic influence;

- deciduous area;

- steep banks with grassy vegetation;

- cloddish underlayer with large stones;

- average depth 35-45 cm.

- bioderm developed in the summer months;

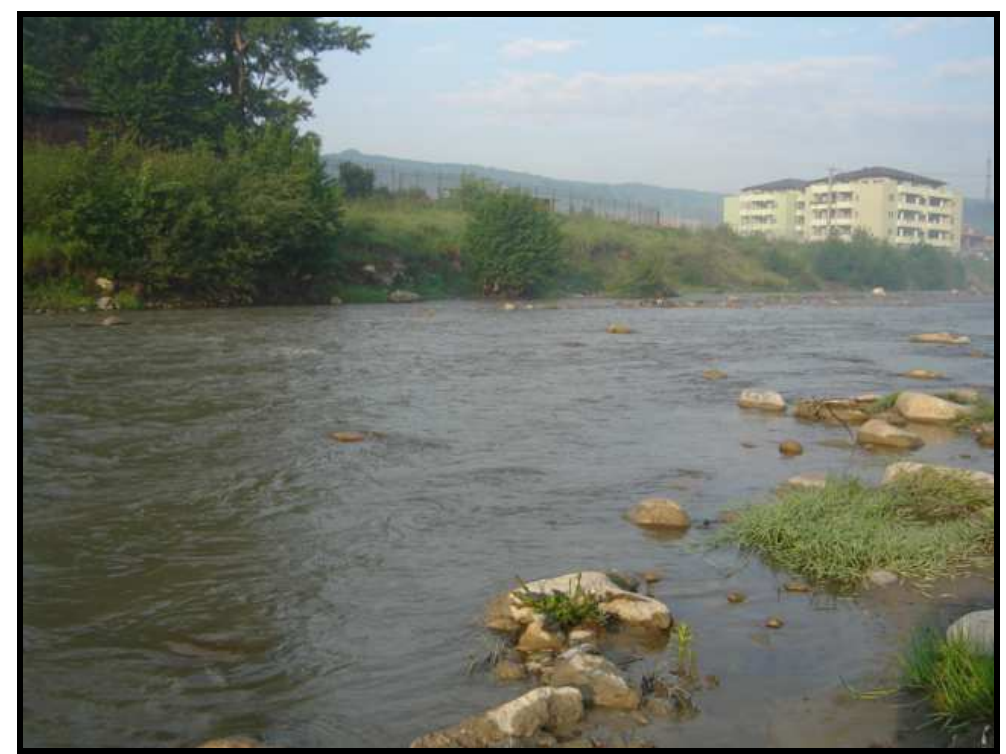

Figure 3. Olăneşti Sampling Station

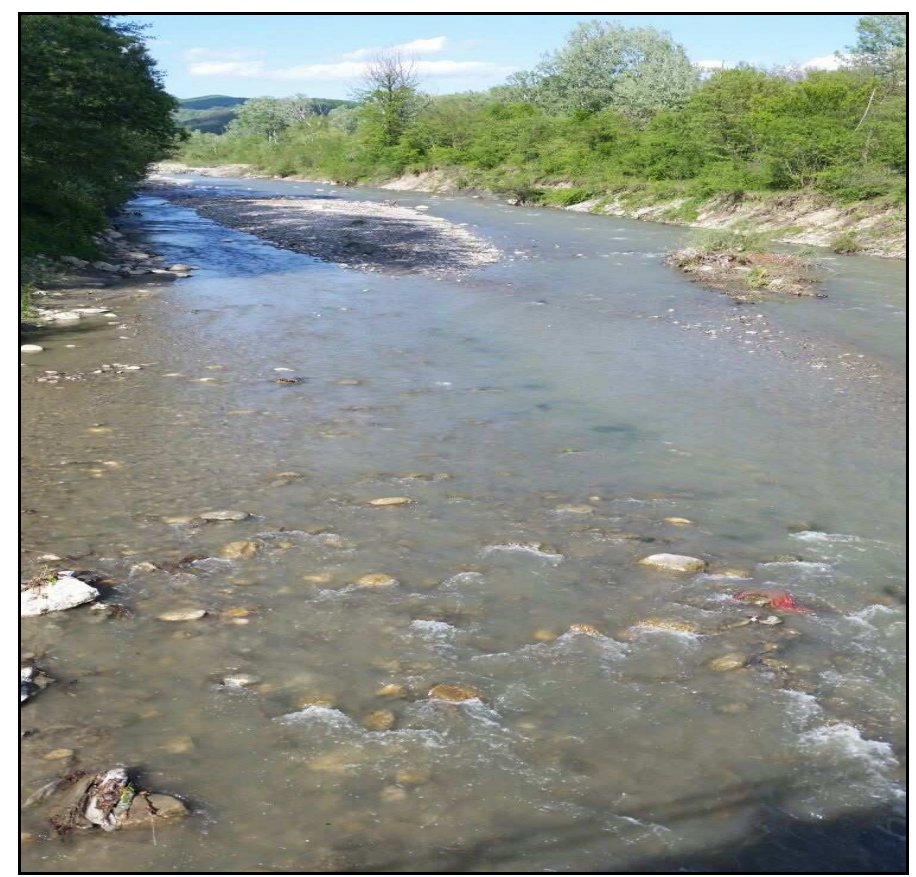

Figure 4. Cheia Sampling Station 


\begin{tabular}{lrr}
\hline & $\begin{array}{c}\text { Current Trends in Natural Sciences } \\
\text { Vol. 9, Issue 17, pp. 322-336, 2020 }\end{array}$ \\
& $\begin{array}{c}\text { https://doi.org/10.47068/ctns.2020.v9i17.041 } \\
\text { Current Trends in Natural Sciences (CD-Rom) } \\
\text { Current Trends in Natural Sciences (on-line) }\end{array}$ & ISSN: 2284-9521 \\
ISSN: 2284-953X & ISSN-L: 2284-9521 \\
ISSN-L: 2284-9521 & \\
\hline
\end{tabular}

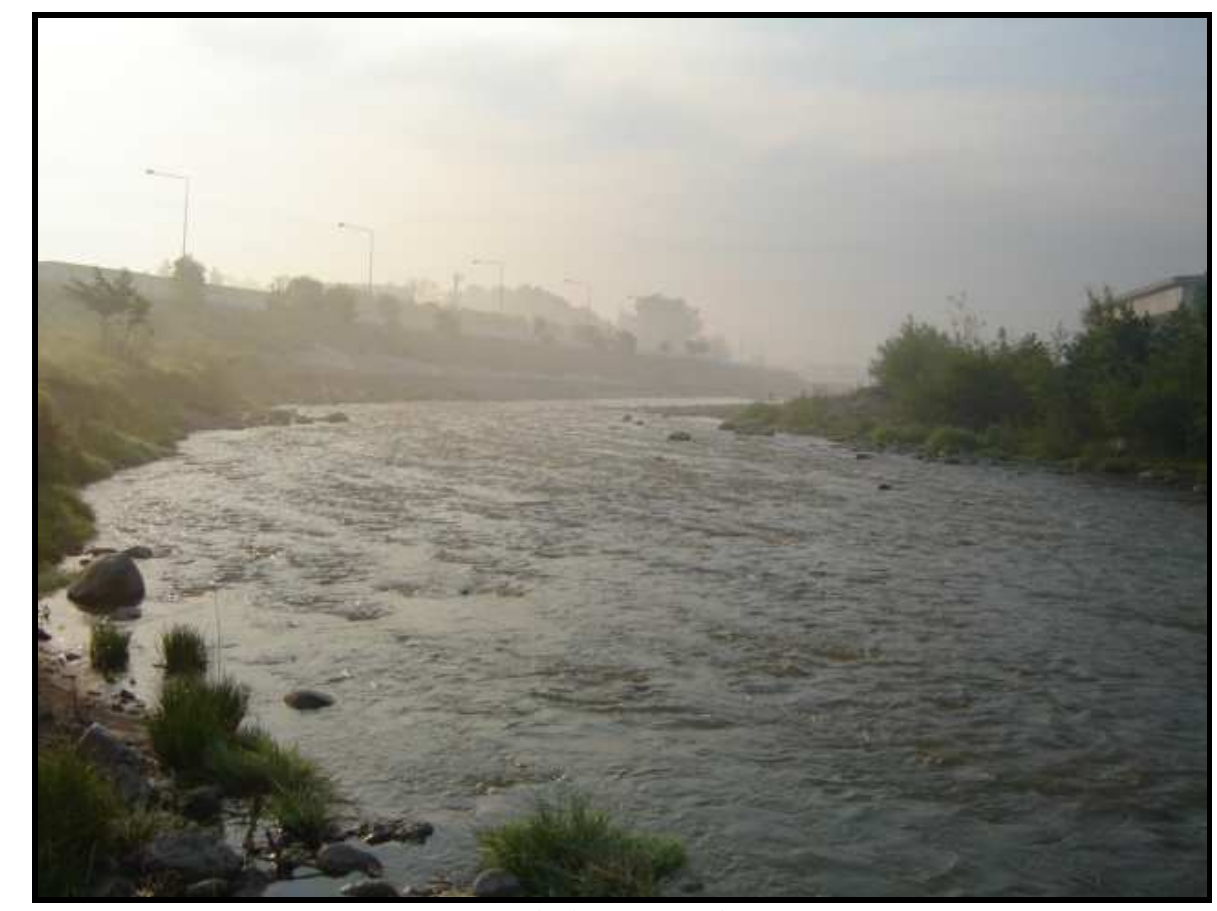

Figure 5. Vlădeşti Sampling Station

For the quantitative analysis, samples were made with benthic mesh - Surber Sampling, with a frame of $40 \times 40 \mathrm{~cm}$ delimiting an area of $0.16 \mathrm{~m}^{2}$. The mesh size is $200 \mu \mathrm{m}$. The stones were washed and brushed in the watercourse.

Determining the density of the organisms in the benthic mesh was made by the rule of three, taking the unit of measurement $\mathrm{m} 2$ as standard, in this case having a surface of the mesh delimiting $0.16 \mathrm{~m}^{2}$. The samples were fixed in 4-5\% formalin and transported to the Hydrobiology Laboratory in labeled plastic jars. The samples were sorted in the Hydrobiology laboratory within the University of Piteşti. The resulting organisms were placed in $80 \%$ ethyl alcohol recipients.

An I.O.R type binocular magnifier (stereomicroscope) was used for sorting. Representative determinants from the Romanian and foreign specialized literature were used to identify the taxa.

Natural or artificial underlayers were used to take phytobenthos samples. Samples must be taken from the same type of underlayer for the same watercourse or lake, for watercourses or lakes of the same typological category and the comparison of the results. Qualitative or semi-quantitative samples can be taken from natural underlayers.

The most common sampling procedure recommends scraping the underlayer (stones, wood, underwater plants or other submerged underlayers) with a scraper. The dimensions (blade) of the scraper must be known for quantitative sampling.

Submerged stones with a smooth and uniform surface are usually scraped. Stones at a depth of approximately $25-50 \mathrm{~cm}$ will be chosen, which have been under water for at least 14-21 days, and the scraped surface will be between $6-20 \mathrm{~cm}^{2}$. The scraped surface will be determined with the maximum possible precision, being equal in size for all control sections. Extraction of the stones from the water will be done with the utmost care so as not to disturb (wash) the phytobenthos, and so that the results to be as accurate as possible.

In the case of quantitative samples, it is suggested to choose stones that have a smooth homogeneous surface and a 100\% coverage with elements of microphytobenthos. 
For semi-quantitative and qualitative sampling, phytobenthos is sampled from hard submerged supports by scraping (with scraper, blade, teaspoon, spatula, etc.) or by washing, without taking into account the dimensions of the analyzed surface. It is recommended to compare the sample size.

Sampling can be done directly from the surface of fine sediments with a teaspoon, Janet-type syringe or core-type devices. These are piston devices, consisting of cylindrical tubes that penetrate the sediment mass. They can be closed with stoppers, at the top or at both ends. They can be provided with a steel cutting head at the bottom. The devices are made of transparent plastic to allow seeing the sediment core. Core-type devices are expensive and more difficult to get, so it is recommended to sample the surface layer of sediment with a teaspoon or spatula. If sampling is not possible with the above-mentioned device, one can use a gripping dredge. The top layer of about 3 $\mathrm{mm}$ of sediment can be removed from the dredged sample with a spatula or teaspoon. Handling of sampling devices and samples must be done with great care to avoid the loss of biological material by drainage. Sampling of phytobenthos from fine, mobile underlayers is possible for semiquantitative and quantitative evaluations.

After specifying the specific composition and density, it is recommended to evaluate the ecological status of water units based on phytobenthos, using the Pantle-Buck method, which is accepted by all countries in the Danube area. Bioindicator forms are used in the specialized studies both in the country and in Europe.

\section{RESULTS AND DISCUSSIONS}

The flow of Olăneşti River registered significant variations throughout the study (figure 6), with the highest value in October due to the abundant rainfall, and the lowest value in August, due to the drought.

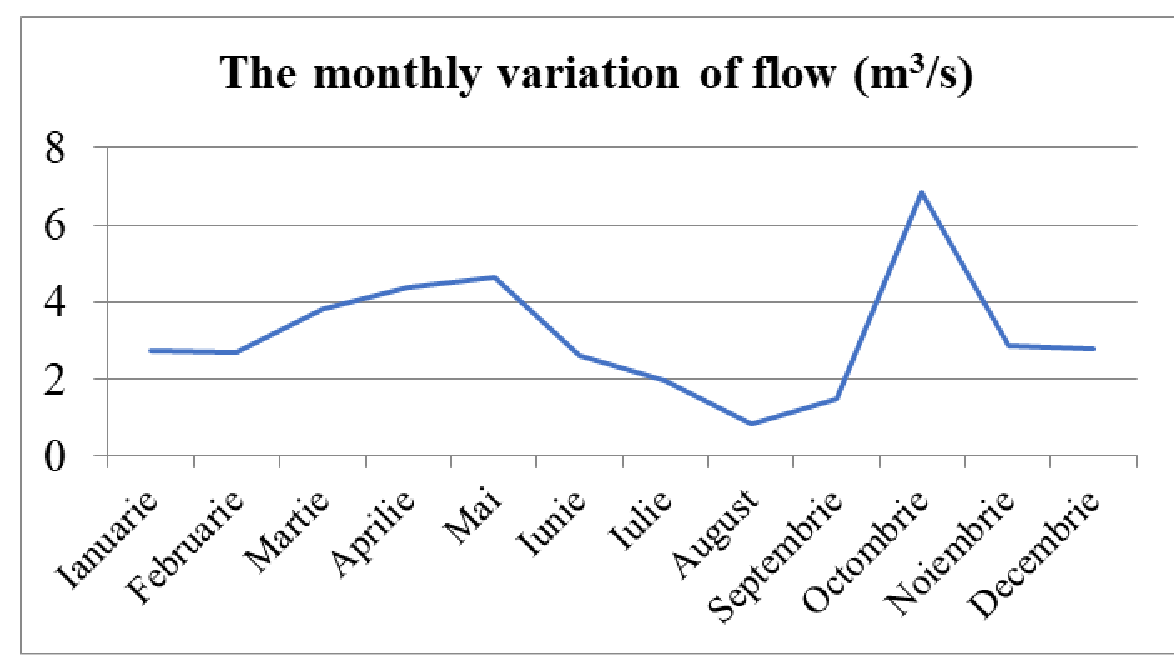

Figure 6. The monthly variation of Olănești River flow

The $\mathrm{pH}$ also varied, but to a much lesser extent (Figure 7), with the highest value in August and the lowest in October, because the $\mathrm{pH}$ varies in inverse ration to the river flow.

Olăneşti sampling station:

- in phytobenthos (table 1) 23 species belonging to the Bacillariophyta cluster were identified. The highest density was recorded in Achnanthes minutissima, with 119 individuals $/ \mathrm{m}^{2}$, and the lowest in 
Current Trends in Natural Sciences

Vol. 9, Issue 17, pp. 322-336, 2020

https://doi.org/10.47068/ctns.2020.v9i17.041

Current Trends in Natural Sciences (on-line)

ISSN: 2284-953X

ISSN-L: 2284-9521
Current Trends in Natural Sciences (CD-Rom) ISSN: 2284-9521

ISSN-L: 2284-9521

Hantzchia amphioxys and Nitzschia sigmoidea (1 individual $/ \mathrm{m}^{2}$ ). The total density was 400 individuals $/ \mathrm{m}^{2}$.

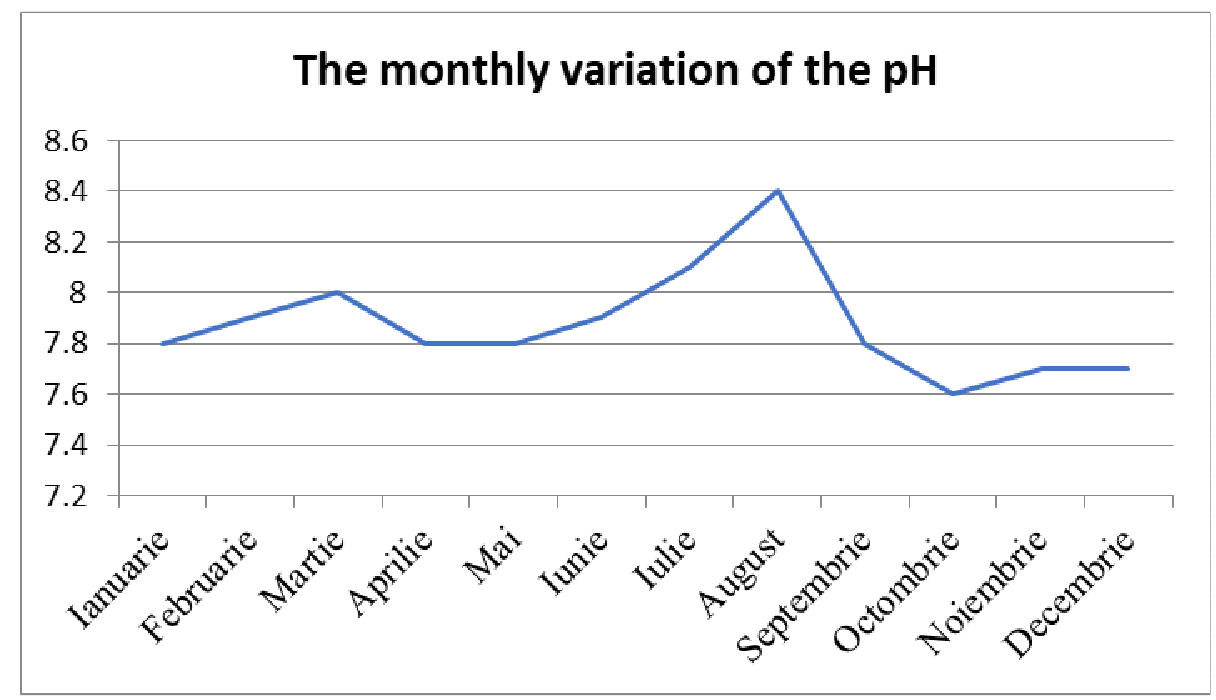

Figure 7. The monthly variation of Olăneşti River $\mathrm{pH}$

Table 1. Structure of phytobenthic biocenosis in the upstream Olăneşti sampling station

\begin{tabular}{|c|l|l|c|}
\hline \multicolumn{4}{|c|}{ PHYTOBENTOS - Olăneşti } \\
\hline No. & \multicolumn{1}{|c|}{ Phyllum } & \multicolumn{1}{c|}{ Species } \\
\hline 1. & Bacillariophyta & Achnantes lanceolata & Counted units \\
\hline 2. & & Achnanthes minutissima & 21 \\
\hline 3. & Amphora ovalis & 119 \\
\hline 4. & & Cocconeis pediculus & 4 \\
\hline 5. & & Cocconeis placentula & 19 \\
\hline 6. & Cymatopleura solea & 78 \\
\hline 7. & Cymbella ventricosa & 2 \\
\hline 8. & Cymbella lanceolata & 38 \\
\hline 9. & Cymbella naviculiformis & 3 \\
\hline 10. & Gomphonema olivaceum & 9 \\
\hline 11. & Gomphonema parvulum & 8 \\
\hline 12. & Hantzschia amphioxys & 7 \\
\hline 13. & Melosira varians & 1 \\
\hline 14. & & Navicula cryptocephala & 3 \\
\hline 15. & Navicula gracilis & 6 \\
\hline 16. & Navicula lanceolata & 23 \\
\hline 17. & & Navicula radiosa & 14 \\
\hline 18. & Navicula rhyncocephala & 3 \\
\hline 19. & Nitzschia palea & 6 \\
\hline 20. & & Nitzschia sigmoidea & 9 \\
\hline 21. & & Reimerla sinuata & 1 \\
\hline 22. & Surirella ovata & 2 \\
\hline 23. & & Synedra ulna & 6 \\
\hline Total units counted & & 18 \\
\hline & & & 400 \\
\hline
\end{tabular}

- in macrozoobenthos (table 2) 17 species belonging to 13 families from 5 orders were identified. The highest density was recorded in Baëtis alpinus from Baëtidae, with 84 individuals/ $\mathrm{m}^{2}$, and the lowest density of 8 individuals $/ \mathrm{m}^{2}$ was recorded in Gammarus balcanicus from Gammaridae, 


\section{Current Trends in Natural Sciences}

Vol. 9, Issue 17, pp. 322-336, 2020

https://doi.org/10.47068/ctns.2020.v9i17.041

Current Trends in Natural Sciences (on-line)

ISSN: 2284-953X

Current Trends in Natural Sciences (CD-Rom)

ISSN: 2284-9521

ISSN-L: 2284-9521

ISSN-L: 2284-9521

Protonemoura intricata from Nemouridae and Ablabesmyia sp. from Chironomidae. The total density was 452 individuals $/ \mathrm{m}^{2}$.

\section{Cheia sampling station:}

- in phytobenthos (table 3) 24 species belonging to the Bacillariophyta cluster were identified.

The highest density was recorded in Cymbella verticosa, with 74 individuals $/ \mathrm{m}^{2}$ and the lowest density of 1 individual $/ \mathrm{m}^{2}$ was recorded in Ceratoneis arcus and Cymatopleura solea. The total density was 400 individuals $/ \mathrm{m}^{2}$.

Table 2. Structure of the macrozoobenthic biocenosis in the upstream Olăneşti sampling station

\begin{tabular}{|c|c|c|c|c|}
\hline \multicolumn{5}{|c|}{ MACROZOOBENTHOS - Olăneşti } \\
\hline No. & Order & Family & Species & $\begin{array}{c}\text { Density } \\
\text { individuals / sqm }\end{array}$ \\
\hline 1. & Amphipoda & Gammaridae & Gammarus balcanicus & 8 \\
\hline 2. & Ephemeroptera & Baëtidae & Baëtis rhodani & 64 \\
\hline 3. & & & Baëtis alpinus & 84 \\
\hline 4. & & & Baëtis vernus & 72 \\
\hline 5. & & Ephemerelidae & Ephemerella ignita & 28 \\
\hline 6. & & Heptageniidae & Ecdyonurus subalpinus & 28 \\
\hline 7. & & & Rhithrogena semicolorata & 32 \\
\hline 8. & & Leptophlebiidae & Habroleptoides modesta & 16 \\
\hline 9. & Plecoptera & Leuctridae & Leuctra sp. & 16 \\
\hline 10. & & Perlidae & Perla marginata & 24 \\
\hline 22. & & Nemouridae & Protonemoura intricata & 8 \\
\hline 12. & Trichoptera & Hydropsychidae & Hydropsyche instabilis & 12 \\
\hline 13. & & Rhyacophilidae & Rhyacophila dorsalis & 16 \\
\hline 14. & Diptera & Chironomidae & Ablabesmyia sp. & 8 \\
\hline 15. & & & Polypedilium convictum & 12 \\
\hline 16. & & Simuliidae & Simulium sp. & 12 \\
\hline 17. & & Tabanidae & Tabanus spodaptenis & 12 \\
\hline \multicolumn{4}{|c|}{ Total density (individuals / sqm) } & 452 \\
\hline \multicolumn{4}{|c|}{ Number of family } & 13 \\
\hline \multicolumn{4}{|c|}{ SAPROB S INDEX OF THE STATION } & 1,65 \\
\hline
\end{tabular}

- in macrozoobenthos (table 4) 14 species belonging to 11 families from 5 orders were identified.

The highest density of 96 individuals $/ \mathrm{m}^{2}$ was recorded in Baëtis rhodani from Baëtidae, and the lowest density of 8 individuals $/ \mathrm{m}^{2}$ was recorded in Gammarus balcanicus from Gammaridae, Ablabesmyia sp. and Polypedilium convictum from Chironomidae and Simulium sp. from Simulidae. The total density was 356 individuals $/ \mathrm{m}^{2}$.

- in phytobenthos (table VI.5) 24 species belonging to Bacillariophyta cluster were identified.

The highest density of 88 individuals $/ \mathrm{m}^{2}$ was recorded in Achnanthes minutissima, and the lowest density of 4 individuals $/ \mathrm{m}^{2}$ was recorded in Cocconeides pediculus, Nitzschia acicularis and Nitzschia sigmoidea. The total density was 401 individuals $/ \mathrm{m}^{2}$.

- in macrozoobenthos (table VI.6) 11 species belonging to 9 families from 5 different orders were identified.

The highest density of 84 individuals $/ \mathrm{m}^{2}$ was recorded in Baëtis rhodani from Baëtidae, and the lowest density of 8 individuals $/ \mathrm{m}^{2}$ was recorded in Nais alpina from Naididae, Hydropsyche instabilis from Hydroosychidae and Dicranota sp. from Pediciidae. The total density was 292 individuals $/ \mathrm{m}^{2}$. 


\section{Current Trends in Natural Sciences}

Vol. 9, Issue 17, pp. 322-336, 2020

https://doi.org/10.47068/ctns.2020.v9i17.041

Current Trends in Natural Sciences (on-line)

ISSN: 2284-953X

Current Trends in Natural Sciences (CD-Rom)

ISSN: 2284-9521

ISSN-L: 2284-9521

ISSN-L: 2284-9521

Table 3. Structure of the phytobenthic biocenosis in the upstream Cheia sampling station

\begin{tabular}{|c|l|l|c|}
\hline \multicolumn{2}{|c|}{ PHYTOBENTOS - Cheia } \\
\hline No. & \multicolumn{1}{|c|}{ Phyllum } & \multicolumn{1}{c|}{ Species } & Counted units \\
\hline 1. & Bacillariophyta & Achnanthes minutissima & 69 \\
\hline 2. & & Amphora ovalis & 2 \\
\hline 3. & & Ceratonies arcus & 1 \\
\hline 4. & & Cocconeis pediculus & 15 \\
\hline 5. & & Cocconeis placentula & 66 \\
\hline 6. & & Cymatopleura solea & 1 \\
\hline 7. & Cymbella affinis & 6 \\
\hline 8. & & Cymbella lanceolata & 12 \\
\hline 9. & Cymbella naviculiformis & 8 \\
\hline 10. & & Cymbella ventricosa & 74 \\
\hline 11. & & Diatoma hiemale & 12 \\
\hline 12. & Diatoma vulgaris & 3 \\
\hline 13. & & Gomphonema olivaceum & 6 \\
\hline 14. & & Melosira varians & 3 \\
\hline 15. & & Navicula gracilis & 32 \\
\hline 16. & & Navicula lanceolata & 29 \\
\hline 17. & & Navicula viridula & 8 \\
\hline 18. & & Nitzschia palea & 8 \\
\hline 19. & & Nitzschia sigmoidea & 2 \\
\hline 20. & & Rhoicosphenia curvata & 6 \\
\hline 21. & & Surinella ovata & 11 \\
\hline 22. & & Synedra acus & 6 \\
\hline 23. & & Synedra ulna & 11 \\
\hline 24 & & Tryblionela apiculata & 9 \\
\hline Total units counted & & 400 \\
\hline & & & \\
\hline
\end{tabular}

Table 4 Structure of the macrozoobenthic biocenosis in the upstream Cheia sampling station

\begin{tabular}{|c|c|c|c|c|}
\hline \multicolumn{5}{|c|}{ MACROZOOBENTHOS - Cheia } \\
\hline No. & Order & Family & $\begin{array}{l}\text { Species } \\
\end{array}$ & $\begin{array}{c}\text { Density } \\
\text { individuals / sqm }\end{array}$ \\
\hline 1. & Amphipoda & Gammaridae & Gammarus balcanicus & 8 \\
\hline 2. & Ephemeroptera & Baëtidae & Baëtis rhodani & 96 \\
\hline 3. & & & Baëtis alpinus & 72 \\
\hline 4. & & Ephemerellidae & Ephemerella ignita & 28 \\
\hline 5. & & Heptageniidae & Ecdyonurus subalpinus & 12 \\
\hline 6. & & & Rhithrogena semicolorata & 24 \\
\hline 7. & Plecoptera & Leuctridae & Leuctra sp. & 16 \\
\hline 8. & & Perlidae & Perla marginata & 28 \\
\hline 9. & & Nemouridae & Protonemoura intricata & 12 \\
\hline 10. & Trichoptera & Rhyacophilidae & Rhyacophila dorsalis & 12 \\
\hline 11. & Diptera & Chironomidae & Ablabesmyia sp. & 8 \\
\hline 12. & & & Polypedilium convictum & 8 \\
\hline 13. & & Simuliidae & Simulium sp. & 8 \\
\hline 14. & & Pediciidae & Dicranota sp. & 24 \\
\hline \multicolumn{4}{|c|}{ Total density (individuals / sqm) } & 356 \\
\hline \multicolumn{4}{|c|}{ Number of family } & 11 \\
\hline \multicolumn{4}{|c|}{ SAPROB S INDEX OF THE STATION } & $\mathbf{1 , 5 5}$ \\
\hline
\end{tabular}




\section{Vlădeşti sampling station:}

Table 5. Structure of the phytobenthic biocenosis in the upstream Vlădeşti sampling station

\begin{tabular}{|c|l|l|c|}
\hline \multicolumn{2}{|c|}{ PHYTOBENTOS - Vlădeşti } \\
\hline No. & \multicolumn{1}{|c|}{ Phyllum } & \multicolumn{1}{c|}{ Counted units } \\
\hline 1. & Bacillariophyta & Achnanthes lanceolata & 19 \\
\hline 2. & & Achnanthes minutissima & 58 \\
\hline 3. & & Amphora ovalis & 7 \\
\hline 4. & & Ceratonies arcus & 4 \\
\hline 5. & & Cocconeis pediculus & 11 \\
\hline 6. & & Cocconeis placentula & 42 \\
\hline 7. & & Cymbella ventricosa & 9 \\
\hline 8. & & Gomphonema constrictum & 19 \\
\hline 9. & & Gomphonema olivaceum & 17 \\
\hline 10. & & Gomphonema parvulum & 6 \\
\hline 11. & & Hantzschia amphioxys & 8 \\
\hline 12. & & Melosira varians & 39 \\
\hline 13. & & Navicula cryptocephala & 6 \\
\hline 14. & & Navicula gracilis & 18 \\
\hline 15. & & Navicula gregaria & 11 \\
\hline 16. & & Navicula lanceolata & 12 \\
\hline 17. & & Navicula rhyncocephala & 4 \\
\hline 18. & & Navicula sp. & 19 \\
\hline 19. & & Nitzschia acicularis & 401 \\
\hline 20. & & Nitzschia palea & 11 \\
\hline 21. & & Nitzschia sigmoidea & 18 \\
\hline 22. & & Reimeria sinuata & \\
\hline 23. & & Surirella ovata & \\
\hline 24. & & Synedra ulna & \\
\hline Total units counted & & \\
\hline & & & \\
\hline
\end{tabular}

Table 6. Structure of the macrozoobenthic biocenosis in the upstream Vlădeşti sampling station

\begin{tabular}{|c|l|l|l|c|}
\hline \multicolumn{2}{|c|}{ Order } & \multicolumn{1}{|c|}{ Family } & \multicolumn{1}{c|}{ Species } & $\begin{array}{c}\text { Density } \\
\text { individuals / sqm }\end{array}$ \\
\hline No. & & Naididae & Nais alpina & 8 \\
\hline 1. & Tubificida & Baëtidae & Baëtis alpinus & 84 \\
\hline 2. & Ephemeroptera & Baëtis rhodani & 28 \\
\hline 3. & & & Baëtis melononyx & 16 \\
\hline 4. & & Heptageniidae & Ecdyonurus subalpinus & 24 \\
\hline 5. & & Leuctra nigra & 36 \\
\hline 6. & Plecoptera & Nemouridae & Protonemoura intricata & 16 \\
\hline 7. & & Perlidae & Perla palida & 8 \\
\hline 8. & & Hydropsychidae & Hydropsyche instabilis & 8 \\
\hline 9. & Trichoptera & Chironomidae & Cricotopus sp. & 292 \\
\hline 10. & Diptera & Pediciidae & Dicranota sp. & 9 \\
\hline 11. & & & $\mathbf{1 , 5 0}$ \\
\hline Total density (individuals / sqm) &
\end{tabular}




\section{Current Trends in Natural Sciences}

Vol. 9, Issue 17, pp. 322-336, 2020

https://doi.org/10.47068/ctns.2020.v9i17.041

Current Trends in Natural Sciences (on-line)

ISSN: 2284-953X

Current Trends in Natural Sciences (CD-Rom)

ISSN: 2284-9521

ISSN-L: 2284-9521

ISSN-L: 2284-9521

As regards the ecological spectrum for Olăneşti station (figure 8) Baëtidae species has the highest share of $17 \%$ followed by Chironomidae with $12 \%$ and Heptageniidae with $11 \%$, the other species having a share of $6 \%$.

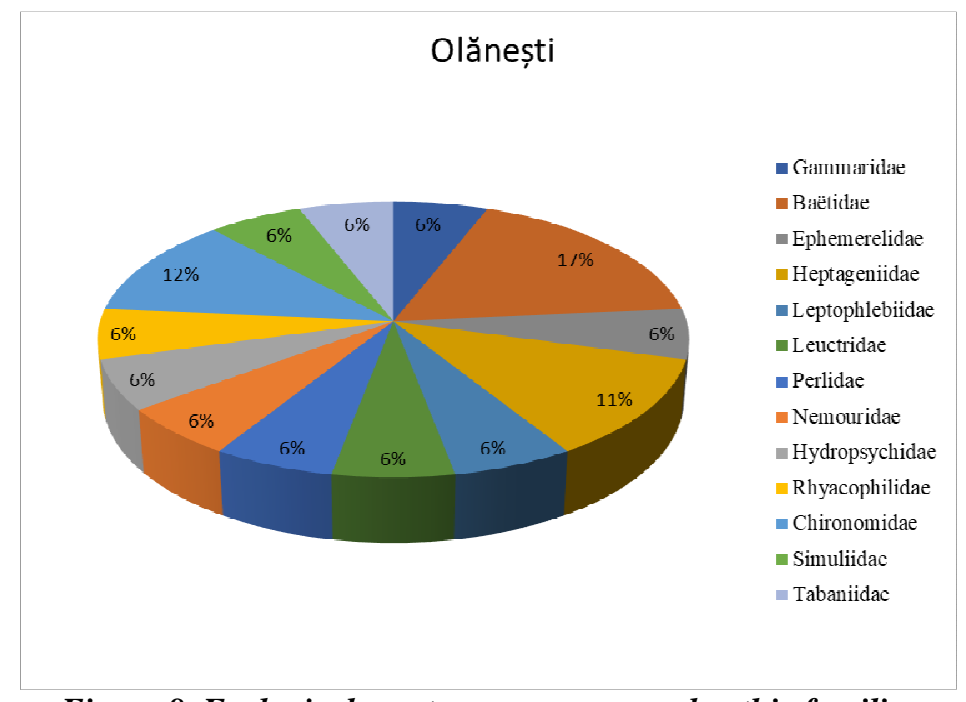

Figure 8. Ecological spectrum on macrozoobenthic families

As regards the ecological spectrum for Cheia station (figure 9) Baëtidae and Heptageniidae species- $15 \%$, have the highest share, followed by Chironomidae - $14 \%$, the rest of the species having a share of $7 \%$.

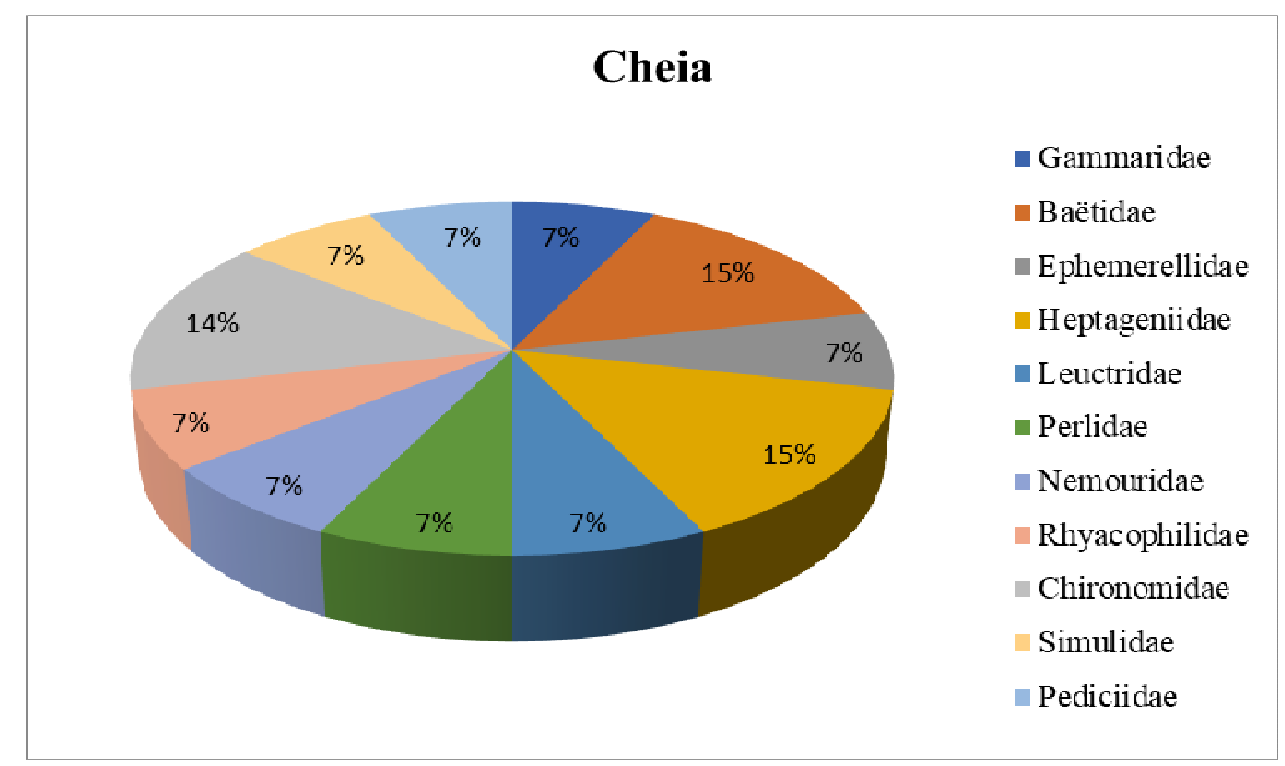

Figure 9. Ecological spectrum on macrozoobenthic species

As regards the ecological spectrum for Vlădeşti station (figure 10) Baëtidae species - 28\% has the largest share, the rest of the species having a share of $9 \%$. 


\section{Current Trends in Natural Sciences}

Vol. 9, Issue 17, pp. 322-336, 2020

https://doi.org/10.47068/ctns.2020.v9i17.041

Current Trends in Natural Sciences (on-line)

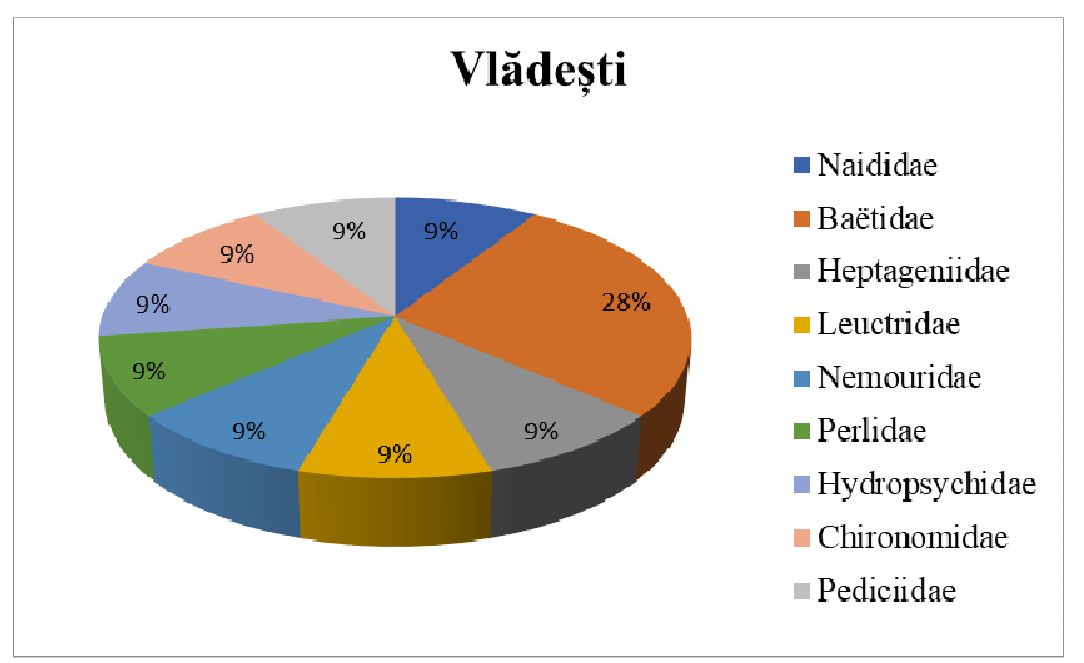

Figure 10. Ecological spectrum on macrozoobenthic species

As regards relative abundance for Olăneşti station (figure 11), species Achnanthes minutissima $30 \%$ has the highest share in the phytobenthic biocenosis, followed by the species Cocconeis placentula with a share of $20 \%$ and Cymbela verticosa with a share of $10 \%$, the other species having a much lower share $(0.5-6 \%)$.

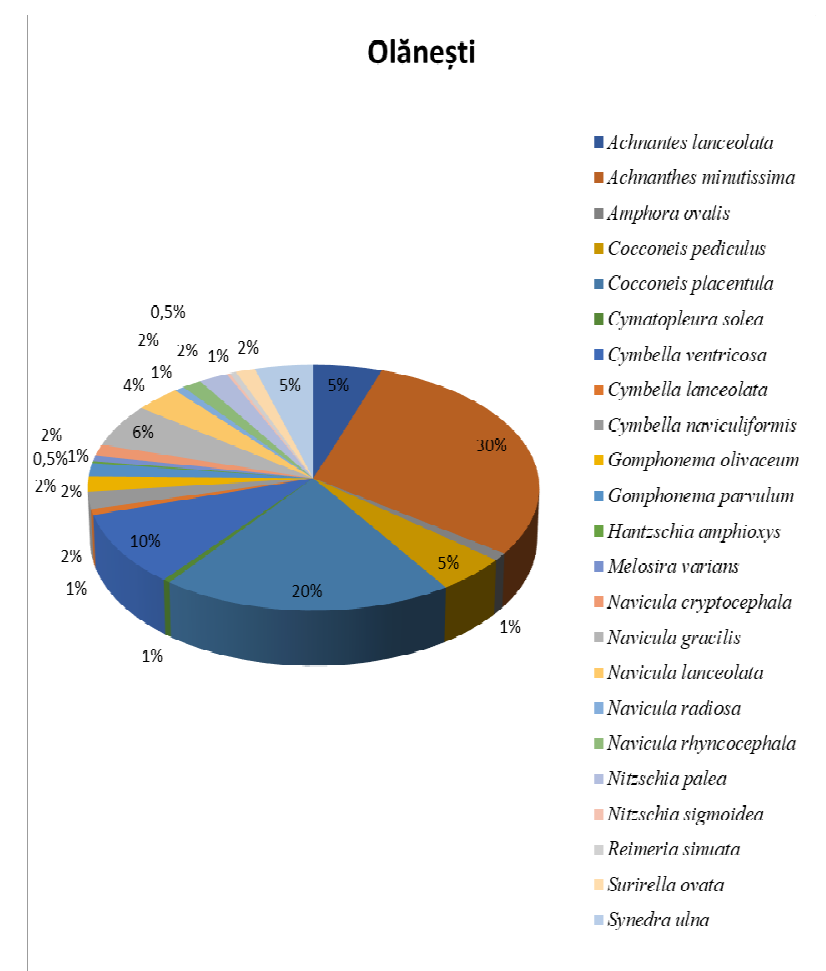

Figure 11. Relative abundance of phytobenthic biocenosis

In the macrozoobenthic biocenosis of Olăneşti station (figure 12), the species Baëtis alpinus - 19\% has the largest share of relative abundance followed by Baëtis vernus - $16 \%$ and Baëtis rhodani $14 \%$, the other species having a much lower share (2-7\%). 


\section{Current Trends in Natural Sciences}

Vol. 9, Issue 17, pp. 322-336, 2020

https://doi.org/10.47068/ctns.2020.v9i17.041

Current Trends in Natural Sciences (on-line)

ISSN: 2284-953X

Current Trends in Natural Sciences (CD-Rom)

ISSN: 2284-9521

ISSN-L: 2284-9521

ISSN-L: 2284-9521

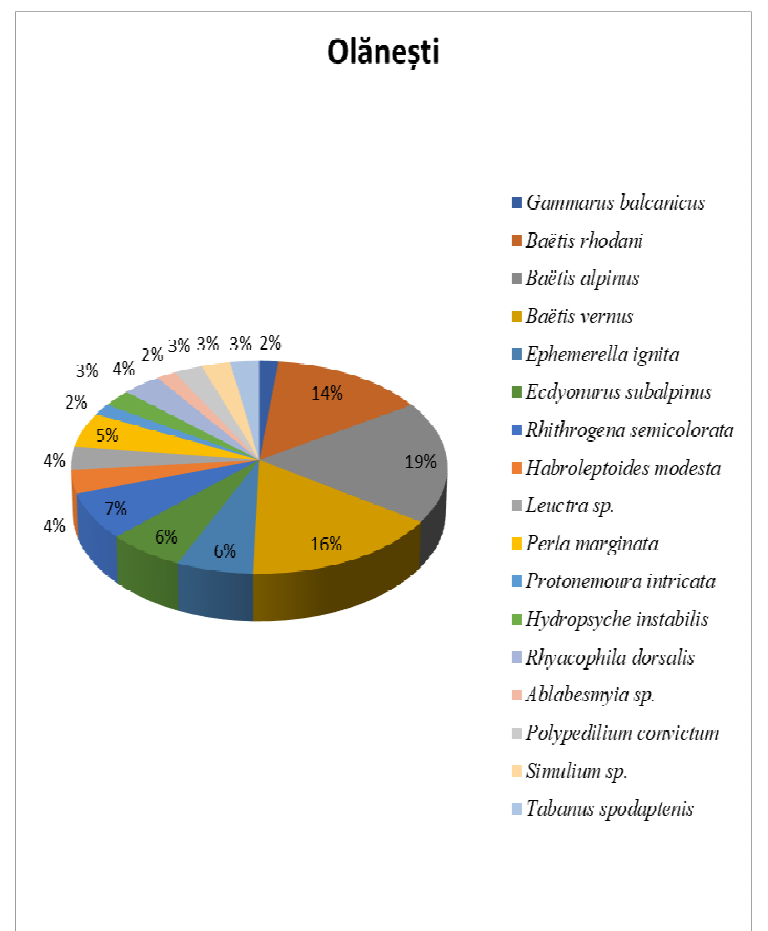

Figure 12. Relative abundance of macrozoobenthic biocenosis

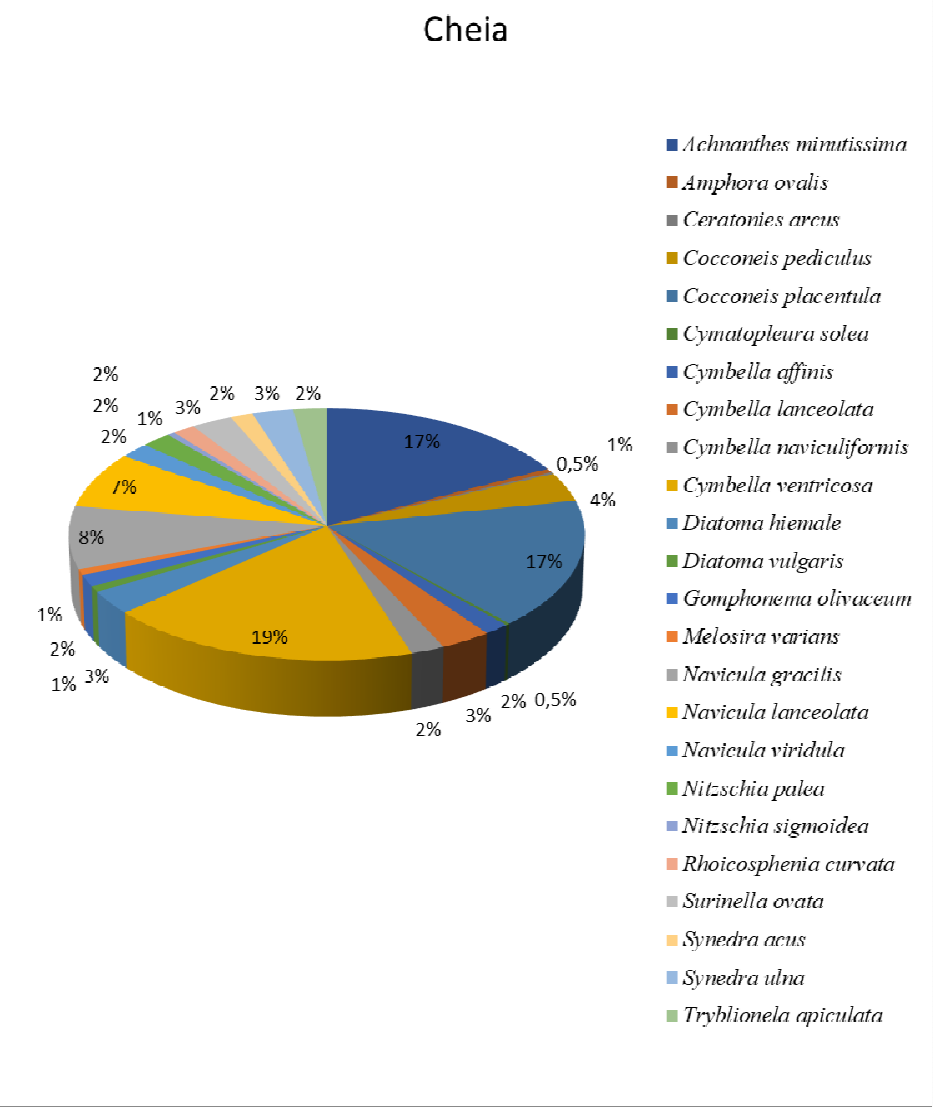

Figure 13. Relative abundance of phytobenthic biocenosis 


\section{Current Trends in Natural Sciences}

Vol. 9, Issue 17, pp. 322-336, 2020

https://doi.org/10.47068/ctns.2020.v9i17.041

Current Trends in Natural Sciences (on-line)

ISSN: 2284-953X

Current Trends in Natural Sciences (CD-Rom)

ISSN: 2284-9521

ISSN-L: 2284-9521

ISSN-L: 2284-9521

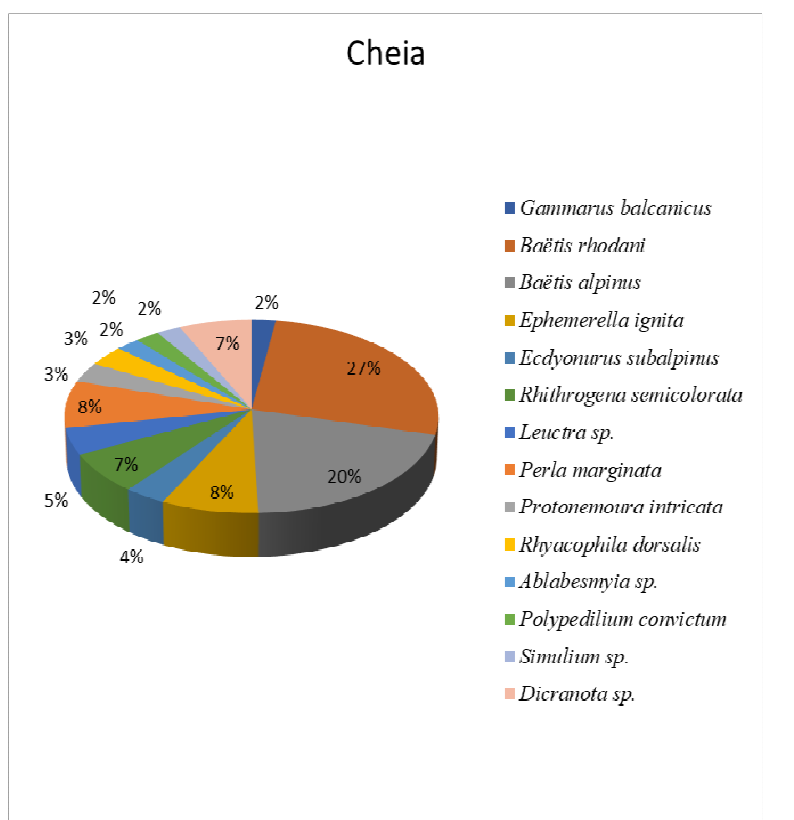

Figure 14. Relative abundance of macrozoobenthic biocenosis

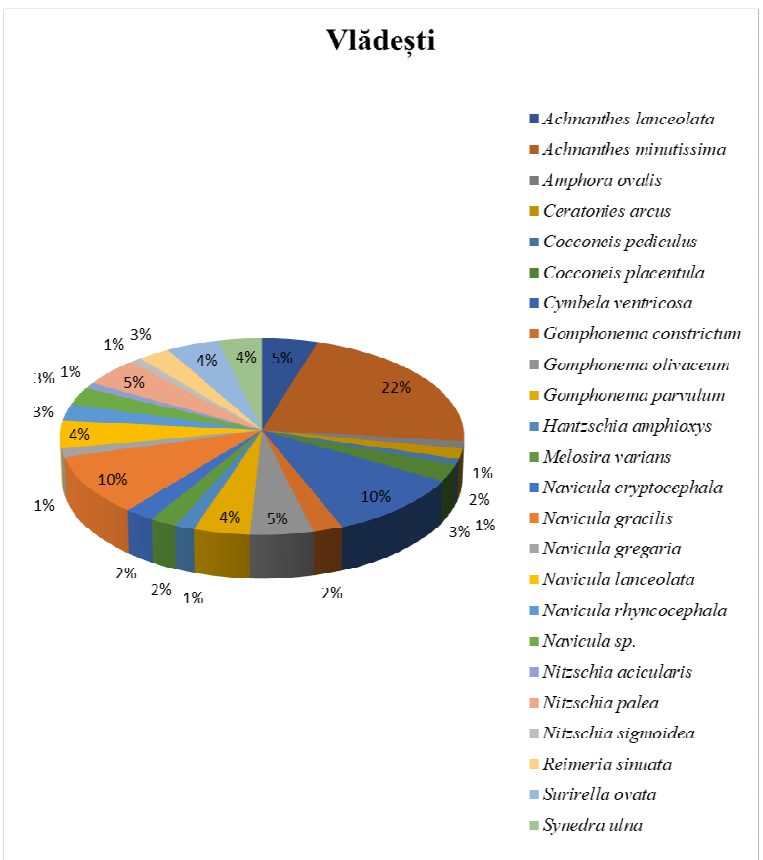

Figure 15. Relative abundance of phytobenthic biocenosis

As regards relative abundance for Cheia station (figure 13) the species Cymbella verticosa - 19\% has the highest share in the phytobenthic biocenosis, followed by Achnanthes minutissima and Cocconeis placentula - 17\%, the other species having a much lower share $(0.5-8 \%)$. In the macrozoobenthic biocenosis of Cheia station (figure 14), the species Baëtis rhodani $27 \%$ has the highest share of relative abundance, followed by Baëtis alpinus - 20\%, the other species having a much lower share $(2-8 \%)$. 


\section{Current Trends in Natural Sciences}

Vol. 9, Issue 17, pp. 322-336, 2020

https://doi.org/10.47068/ctns.2020.v9i17.041

Current Trends in Natural Sciences (on-line)

ISSN: 2284-953X

Current Trends in Natural Sciences (CD-Rom)

ISSN: 2284-9521

ISSN-L: 2284-9521

ISSN-L: 2284-9521

As regards the relative abundance for Vlădeşti station (figure 15), the species Achnanthes minutissima $22 \%$ has the highest share in the phytobenthic biocenosis, followed by Cymbela verticosa and Navicula gracilis - 10\%, the other species having a lower share (1-5\%).

In the macrozoobenthic biocenosis of Vlădeşti station (figure 16), the species Baëtis rhodani - 29\% has the highest share of relative abundance, followed by Baëtis alpinus - $16 \%$ and Protonemoura intricata $-12 \%$, the other species having a much lower share (3-10\%).

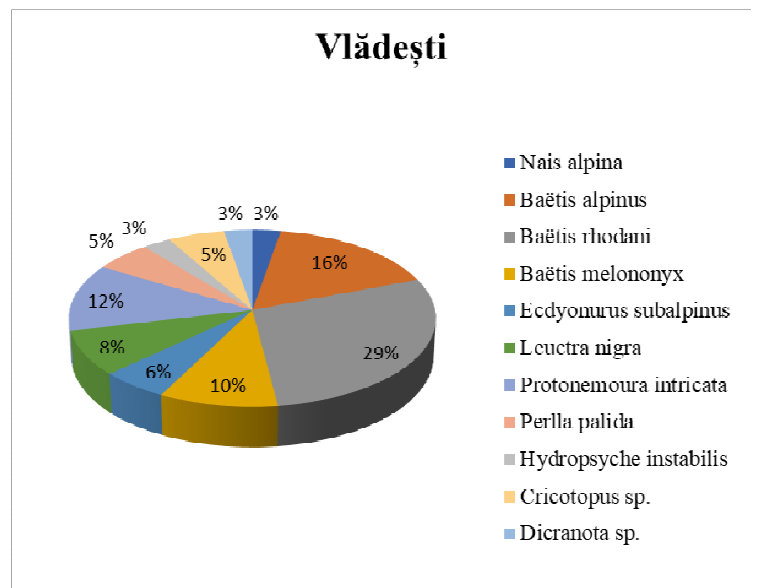

Figure 16. Relative abundance of macrozoobenthic biocenosis

\section{CONCLUSIONS}

Following the research carried out on Olăneşti River regarding the structure of the benthic biocenosis, 34 phytobenthic species belonging to Phyllum Bacillariophyta and 23 zoobenthic species were identified. The analysis of the ecological spectrum reveals the largest share in Baëtidae species. The saprobic value for each station is below 1.65 indicating that the whole river is in the $\beta$ mesosaprobic area, which highlights a good ecological status.

- 34 species were identified in phytobenthos;

- the largest number of species was identified in Cheia and Vlădeşti stations;

- 23 species belonging to 15 families from 6 taxonomic ranks were identified in zoobenthos.

\section{REFERENCES}

Bauernfeind, E., Moog, O. (2000). Mayflies (Insecta:Ephemeroptera) and the assessement of ecological integrity; a methodological approach - In Assesing the Ecological Integrity of Running Waters Edited by JUNGWIRTH, M. \& all., Kluwer Academic Publishers, p. $61-70$.

Bauernfeind, E., Humpesch, U.H. (2001). Die Eintagsfliegen Zentraleuropas (Insecta:Ephemeroptera): Bestimmung und Ökologie [The Mayflies of Central Europe (Insecta: Ephemeroptera): Destination and Ecology] Naturhistorischen Museums in Wien.

Elliott, J.M., Humpesche, U.H., Macan, T.T. (1988). Larvae of the British Ephemeroptera: A key with ecological notes - Freshwatwr Biological Association, Scientific publication No. 49.

Godeanu, S.P. (2002). Diversitatea lumii vii - Determinatorul ilustrat al florei şi faunei României [Diversity of the Living World - The illustrated determinant of Romania's flora and fauna], Vol. II - Apele continentale, Editura Bucura Mond, Bucureşti.

Telcean, I., Cupşa, D. (2005). Ghid practic pentru studiul biologie râurilor [Practical Guide to the Study of River Biology] Ed. Ecozone, Iaşi.

*** (2016). Planul de Management al bazinului hidrografic Olt [River Basin Management Plan Olt] PMBH. Retrieved mai, 2020, from http://www.rowater.ro/daolt/ 